SHS Web of Conferences 2, 00042 (2012)

DOI: $10.1051 /$ shsconf $/ 20120200042$

(C) Owned by the authors, published by EDP Sciences, 2012

\title{
The social representations of the inhabitants of Latvia about the ideal image of a politician
}

\author{
M. Zakrizevska \\ Riga International School of Economics and Business Administration, Latvia
}

\begin{abstract}
The image concept is widely regarded, carefully developed and pragmatically used to obtain some particular benefit, including the social, the psychological as well as the material. Publications, advertisements and other offers can be found on the internet, distributing widely the services and campaigns of image creation. The aim of the research is to investigate the social representations of the inhabitants of Latvia about the ideal image of a politician. The following research questions were put forward: What are the social representations of the inhabitants of Latvia about the ideal image of a politician? What are the differences in social representations about the ideal image of a politician among the representatives of the social groups of the inhabitants of Latvia? The total of 1692 inhabitants of Latvia participated in the research. Research methods: Method of association analysis; Interview of focus groups. Conclusions: The social representations of the inhabitants of Latvia about the ideal image of a politician are, first, as an honest, second, a clever person, third, waiting particular actions and results from politicians, which means working for the benefit of the country, its inhabitants, no for the benefit of his own, fulfilling the promises made. It can be concluded that there exist statistically considerable differences in the choice of associations about an ideal politician $(p<0.05)$ according to the groups of age, place of residence, education, employment and nationality.
\end{abstract}

Key words: social representation, image, politician

Nowadays the creation of the image of politicians is predetermined process, conducted and constructed in a special way, the basic purpose of which is to attract attention to a particular person, party or political event. Very often these images do not correspond to the real personalities, their qualities; they exist only in the consciousness of political supporters as the reflection of the created image. Nevertheless, exactly these images are one of the basic tools that ensure the support, attract attention and votes, transfuse faithfulness and gives hope.

Politicians and political parties very often hire advertising specialists that serve like experts consultants during pre-election campaigns creating the images that correspond to the demands of the electorate (Jost, Sidanius, 2004).

Therefore in the field of the investigation of political images different researches have been carried out over the time, where the very political leaders as well as their supporters have been examined. Systematic beginning of these investigations is connected with the President elections of 1940 in the USA. The results of these first investigations in the USA connected with the President elections of 1940 showed comparatively insignificant changes in the attitude of citizens during the election campaign. Mass media did influence only those who were already sure about their choice and who supported a particular candidate. This phenomenon was designated as selective self-submission to the influence. The main conclusion was that the elector would vote taking into account the "social experience" and mass media only strengthen the previous disposition without changing it radically. Later investigations of 1940s-50s confirmed the obtained conclusions (Klapper, 1960).

Simultaneously many investigations have been started and carried out around the world where famous political leaders have been analysed, their typology has been created as well as the mass consciousness has been studied in order to clarify the constituents of the ideal image of a politician.

This is an Open Access article distributed under the terms of the Creative Commons Attribution License 2.0, which permits unrestricted use, distribution, and reproduction in any medium, provided the original work is properly cited. 


\section{SHS Web of Conferences}

The most influential scientists who have developed the typology of politicians are H. Lasswell, M. Herman, D. Winter and J. Barber.

In order to understand in detail the constituents and qualities of the ideal image of a politician, longterm longitudinal researches have been carried out, as well. For instance, one of them, the duration of which was of almost half a century-from 1952 till 2000, was carried out by W. Benoit and J. McHale. The scientists determined such primary qualities of an ideal politician as morality, ability to lead, empathy and cordiality (Benoit, McHale, 2003).

Today, it is up to date social representations researches. S. Moscovici who is the founder of the theory of social representations has defined social representations as totality of notions, statements and explanations that appear in everyday life in the course of interpersonal communication (Moscovici, 1984). These are some kind of points of reference that assure perspective from which an individual or a group can observe and interpret events, situations, etc. These points of reference are based on concepts that are used by a person in communication with other individuals (Moscovici, 1981).

Taking into account the abovementioned considerations as well as the topicality and significance of the subject in the context of scientific research and in the aspect of practice of image understanding, creation and development, in Latvia a research on social representations of the inhabitants of Latvia about the ideal image of a politician was carried out.

The aim of the research is to investigate the social representations of the inhabitants of Latvia about the ideal image of a politician.

The following research questions were put forward: What are the social representations of the inhabitants of Latvia about the ideal image of a politician? What are the differences in social representations about the ideal image of a politician among the representatives of the social groups of the inhabitants of Latvia?

\section{Materials and methods}

It was used two data collection methods: Method of association analysis (used in the research of social representations made by Di Giacomo, 1980; Doise, Clémence, Lorenzi-Cioldi, 1993; Tsoukalas, 2006; Reņge, Austers, 2004; Ruža, 2006; Zakriževska, 2009; etc.). Interview of focus groups (used in the research of social representations made by Foster, 2001; Markova, Moodie, Plichotva, 2000; Guilbert, Dufort, St-Laurent, 2004; Zakriževska, 2009; etc.).

The total of 1692 inhabitants of Latvia participated in the research.

\section{Results of the method of association analysis}

In order to answer the first research question: what are the social representations of the inhabitants of Latvia about the ideal image of a politician, firstly the results that were obtained with the method of association analysis are shown. Originally gathered data-all associations of the inhabitants of Latvia ( $n=4727$ ), using the qualitative method of data processing, were divided into 30 association groups.

With the quantitative method of data processing the frequency of associations or association groups was calculated, the criterion chosen was the associations that were mentioned the most frequently.

The results obtained were summarized and can be clearly seen in the Figure 1, where the division of the social representations of the inhabitants of Latvia about the ideal image of a politician according to the frequency is shown.

When studying the social representations of the inhabitants of Latvia about the ideal image of a politician, the following results were obtained: the most frequently mentioned association is honesty $13.8 \%$. The second most important group of associations when characterizing the image of an ideal politician is - clever, well-read, thinking, understanding, knowing $-11.8 \%$. The third most important group of associations is connected with the actions and results expected from politicians $-10.2 \%$. The expected action of the ideal politician and the results that are mentioned by the inhabitants of Latvia 
Int. Conf. SOCIETY. HEALTH. WELFARE; Congr. of Rehabilitation Doctors of Latvia

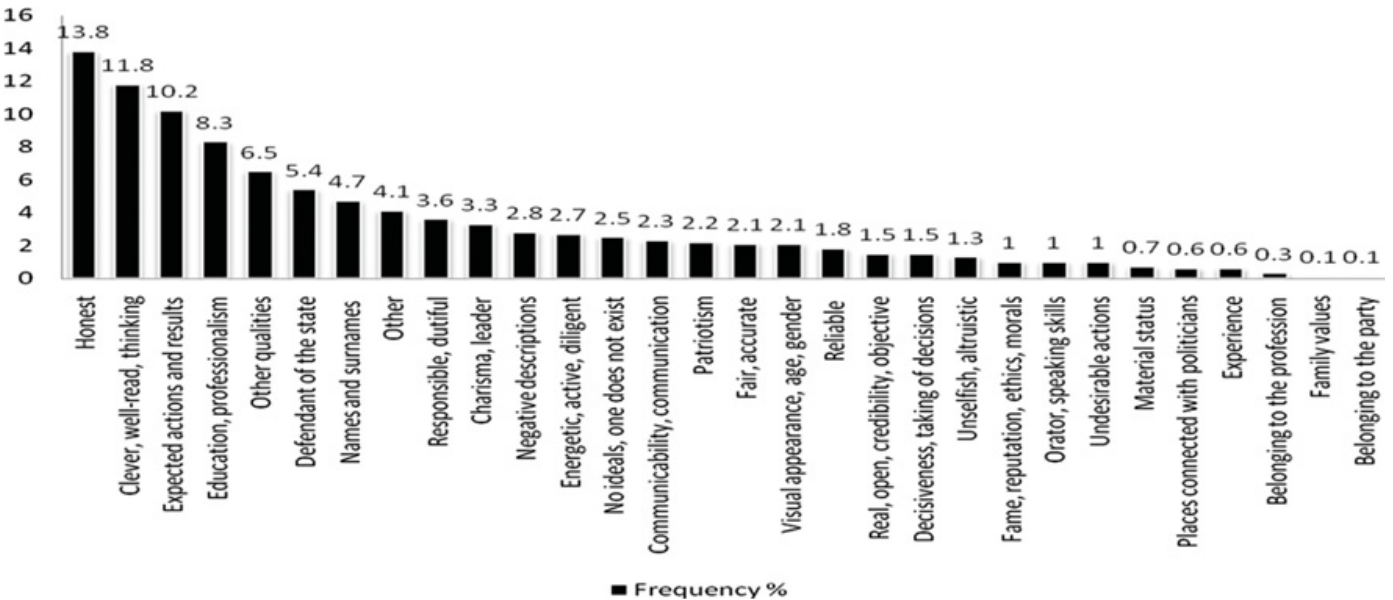

Figure 1. Division of the social representations of the inhabitants of Latvia about the ideal image of a politician according to the frequency.

are, for instance, to fulfil one's promises, improve the economical situation in the country, increase the welfare of the country, take care of all social strata, search solutions to the existing economical problems etc. The fourth place among the associations is occupied by education, professionalism and competence $-8.3 \%$. The fifth place was occupied by other positive characteristics of a politician that were not distinguished separately $-6.5 \%$, for instance, good-natured, confident, healthy, demanding, realistic, tactful, etc. (see Figure 1).

It should be mentioned that the inhabitants of Latvia do not consider the importance of family to be an essential part of the image of an ideal politician $-0.1 \%$.

Thus, it can be concluded that the image of an ideal politician is perceived by the inhabitants of Latvia as honest, clever person that works for the benefit of the country and its inhabitants and achieves particular results.

\section{Results of the focus group interviews}

In order to answer to the first and second research question: what are the social representations of the inhabitants of Latvia about the ideal image of a politician and what are the differences in social representations about the ideal image of a politician among the representatives of the social groups of the inhabitants of Latvia, the method of focus group interview was used. In total 10 focus group interviews were conducted in the regions of Latvia: Latgale, Vidzeme, Kurzeme, Zemgale and in the capital Riga. The focus groups were organized taking into account the age of respondents, which was: 18-24 years old; 25-40 years old; 41-65 years old and respondents older than 65 . In order to answer the second research question, the results obtained from the focus group interviews were compared taking into account the age of respondents.

The results obtained from focus group interviews allow to conclude that the social representations of the inhabitants of Latvia about the ideal image of a politician are like about a person who works for the benefit of the people not of his/her own, who is honest, clever, educated person, fulfils his/her promises. He/she must be available, understanding, simple, must be able to listen to other people. The social representations of the inhabitants of Latvia about the ideal image of a politician are like about a concerned person who wants to change, to improve the situation in the country.

There exist differences between social representations about the age of an ideal politician among the respondents of different age groups. For the inhabitants of Latvia that are 18-40 years old the social 


\section{SHS Web of Conferences}

Table 1. Results of the $p$ Values in the Choice of Associations Depending on the Social Groups of the Inhabitants of Latvia (Method: chi-square).

\begin{tabular}{|l|c|c|}
\hline Social group of the inhabitants of Latvia & $\mathbf{d f}$ & $\mathbf{p}$ \\
\hline Age & $\mathbf{8}$ & $\mathbf{0 , 0 0 1}$ \\
\hline Gender & 4 & 0,735 \\
\hline Place of residence (town, countryside) & $\mathbf{4}$ & $\mathbf{0 , 0 2 4}$ \\
\hline Place of residence according to the region & 16 & 0,478 \\
\hline Education & $\mathbf{1 2}$ & $\mathbf{0 , 0 0 1}$ \\
\hline Employment & $\mathbf{1 6}$ & $\mathbf{0 , 0 0 1}$ \\
\hline Citizenship & 4 & 0,455 \\
\hline Nationality & $\mathbf{8}$ & $\mathbf{0 , 0 0 2}$ \\
\hline
\end{tabular}

df-number of degrees of freedom.

representations about an ideal politician are as about a person who is 30-60 years old. The inhabitants of Latvia that are 41-65 years old admit that an ideal politician may be even up to 70 years old. This means that younger people want to see an ideal politician as a younger person than those who are older.

In the social representations of the inhabitants of Latvia the ideal politician is a person with higher education, preferably in the sphere of law or economics.

The inhabitants of Latvia believe that the family, gender and physical beauty of an ideal politician has no important role; still the visual image must correspond to the norms of business style, etiquette and ethics.

\section{The choice of association about the ideal politician made by the inhabitants of Latvia depending on the different social groups}

In order to answer the second research question: what are the differences in social representations about the ideal image of a politician among the representatives of the social groups of the inhabitants of Latvia, the $\chi^{2}$ test statistics method is used.

The choice of associations about an ideal politician depending on the social groups of the inhabitants of Latvia, the $\mathrm{p}$ values are shown in the Table 1.

Having calculated the $\mathrm{p}$ values, it can be seen that in the association choice about an ideal politician there exist considerable differences with regard to the age groups, place of residence, education, employment and nationality (see Table 1).

It was stated that in the association choice about an ideal politician there exist no statistically considerable differences with regard to the gender, region and citizenship of the respondents $(p>0,05)$, which means that men and women, respondents from different regions of Latvia, citizens and noncitizens choose associations about an ideal politician in approximately the same ratio (see Table 1).

\section{Disscussion}

Taking into account the research results where exist statistically considerable differences, the order of the association choice about the ideal politician of different social groups of the inhabitants of Latvia.

It was stated that there exist statistically significant differences between the age groups in the association choice of an ideal politician $(p<0,01)$. This means that the representatives of different age groups choose associations about an ideal politician in different ratio.

In all age groups respondents choose honesty as the second association about an ideal politician. In the age group of 18-40 years the inhabitants of Latvia choose clever and honest as the first and the second association about the ideal politician. At the same time the respondents belonging to the age 


\section{Int. Conf. SOCIETY. HEALTH. WELFARE; Congr. of Rehabilitation Doctors of Latvia}

group above 65 choose expected actions as the first association about the ideal politician. It could be explained by the fact that people older than 65 are mostly pensioners, not active in the labour market, depend on the state allowances and pensions, respectively, they are directly dependant on the political course of the state and decisions made by politicians. Thus, it could be concluded that these inhabitants of Latvia expect actions from politicians that could improve their social welfare.

At the same it was stated that there exist statistically considerable differences in the choice of associations about an ideal politician with the regard to the place if reference $(p>0,05)$. Respondents living in cities and outside cities choose the associations about the ideal politician in different ratio.

Respondents living in cities and outside them choose clever as the first association about the image of an ideal politician. On the other hand, the ones living in cities choose honest as their second association, while people living outside cities-expected actions. This can be explained by the fact that the infrastructure outside cities is less developed, thus there are less possibilities to find a job or other pastimes. Due to this people wait from politicians actions and results that would improve their social-economical state.

It was stated that there exist statistically important differences in the choice of associations about the ideal politician with respect to the education $(p>0,05)$. This means that the respondents with different levels of education choose associations about the ideal politician with different ratio.

Depending on the level of education there appears a tendency amidst the inhabitants of Latviapeople with basic level of education place associations about the expected actions of the ideal politician in the second place while respondents with the secondary and professional education place them in the third place. But the group of respondents with the higher education place expected actions in the fourth place of associations of an ideal politician. It can be explained in the way that the more educated people are, the less action they wait from others and take more active position in life, try to act themselves using their education as an advantage and starting point. In addition, the group of respondents with the higher education place the education in higher position than the respondents without higher education.

It was found out that there exist statistically significant differences in the choice of associations about the ideal politician with respect to the employment $(p>0,05)$. The respondents with different employment situations choose associations about the ideal politician with different ratio.

Groups of respondents belonging to the status of unemployed and pensioners have mentioned expected actions as the first associations about an ideal politician; that can be explained by the fact that these social groups of the inhabitants of Latvia are less socially protected and await help from the state (politicians). Thus, it is possible that from an ideal politician they wait actions that would improve their socially economical situation. At the same time people working at the state sector place the expected actions in the fourth place that can be explained by the fact that the representatives of this group have greater stability. The state sector workers place the associations about the education of an ideal politician in the third place while the other groups of respondents - in the fourth place. This could be explained by the fact that state sector employees possess higher level of education and higher demands to the education, too. Consequently, the significance of education for an ideal politician is stressed.

It was also stated that there exist statistically important differences in the choice of associations about the ideal politician with respect to the nationality $(p>0,05)$. The respondents of different nationalities choose associations about an ideal politician with different ratio.

The group of respondents - representatives of other nationalities (minorities) - place the accusations about an ideal politician as the defendant of the state interests in the fourth place and the associations connected with the expected activities - in the second place.

Thus, when summarizing the results mentioned before, it can be concluded that in the groups of the inhabitants of Latvia that are older than 65, living outside a city, people with basic education, unemployed, and pensioners an ideal politician is most frequently associated with expected actions and results, since they place these associations on a higher level than other social groups. It can be explained by the fact that these groups of the inhabitants of Latvia are less socially protected and wait some help from the state (politicians). Consequently, it is possible that from an ideal politician they 


\section{SHS Web of Conferences}

wait actions that might improve their socially economical state. At the same time, the inhabitants of Latvia with higher education and working at the state sector place the expected actions of politicians on a lower level. This could be explained by the fact that well-read people wait fewer actions from the surrounding people but take more active position in life and try to act themselves using the education as an advantage and starting point. At the same time, the employees of the state sector might have more important socially economical stability.

\section{Conclusions}

Researches of social representations are an important instrument that can be used in the research of big groups in order to ascertain the thinking, opinions and attitudes of society. It also confirms the topicality of the theory of social representations and the diversity of possibilities in the research of modern social sciences.

It should be indicated that the research of the social representations of the inhabitants of Latvia about the image of an ideal politician has been significant allowing clarifying several topical aspects of the viewpoints and representations of the Latvian society (inhabitants, politicians included), fixing the representations of society in a particular period of time.

On the basis of the results received with the method of association analysis, it can be concluded that the social representations of the inhabitants of Latvia about the ideal image of a politician are, first, as an honest (13.8\%), second, a clever (11.8\%) person, third, waiting particular actions and results from politicians $(10.2 \%)$, which means working for the benefit of the country, its inhabitants, no for the benefit of his own, fulfilling the promises made.

On the basis of the results received with the method of association analysis, it can be concluded that there exist statistically considerable differences in the choice of associations about an ideal politician $(p<0.05)$ according to the groups of age, place of residence, education, employment and nationality.

It should be noted that images are dynamic, they change together with the situation and according to the demands of the society (inhabitants). Thus, this research is important for the representation of modern results that are obtained during the period of crisis in the country that causes changes and affects the whole society.

\section{References}

[1] Benoit, W.L., McHale, J. P. (2003) Presidential candidates' television spots an personal qualities. Southern Communication Journal, 68, p. 319-334.

[2] Di Giacomo, J.P. (1980) Intergroup alliance and rejections within a protest movement (Analysis of the social representations). European Journal of Social Psychology, 10, p. 329-344.

[3] Doise, W., Clémence A., Lorenzi-Cioldi, F. (1993) The Quantitative Analysis of Social Representations. Hertfordshire: Harvester Wheatsheaf.

[4] Guilbert, E., Dufort, F., St-Laurent, L. (2004) The social representation of pregnancy in adolescence. A Quebec study. Can J Public Health, 95 (4), p. 281-284.

[5] Jost, T., Sidanius, J. (eds.). (2004) Political Psychology: Key Readings. New York: Psychology Press Taylor \& Francis.

[6] Reņğe V., Austers, I. (2004) Kvalitatīvās metodes sociālo priekšstatu pētījumos. [Qualitative methods of social representations researches]. LU Raksti. Psiholoǵija, 682. sēj. Rīga: Latvijas Universitātes Akadēmiskais apgāds.

[7] Ruža, A. (2006) Latvijas iedzīvotāju sociālie priekšstati par Eiropas Savienības valstīm. [Latvian inhabitants' social representations of European Union countries]. Promocijas darba kopsavilkums. Daugavpils Universitāte.

[8] Klapper, J.T. (1960) The effects of mass communication. New York: Free Press. 
Int. Conf. SOCIETY. HEALTH. WELFARE; Congr. of Rehabilitation Doctors of Latvia

[9] Markova, I., Moodie, E., Plichova, J. (2000) Democracy as Social representation. In M. Chaib and B. Orfali (eds.). Social Representations and Communicative Processes. Jönköping: Jönköping University Press.

[10] Moscovici, S. (1981) On social representations. In J.P. Forgas (ed.). Social Cognition. London: Academic Press.

[11] Moscovici, S. (1984) The phenomenon of representations. In R. Farr and S. Moscovici (eds.). Social Representations. Cambridge: Cambridge University Press.

[12] Tsoukalas, I. (2006) A Method for Studying Social Representations. Quality \& Quantity, 40, p. 959-981.

[13] Zakriževska, M. (2009) Ārstu un pedagogu sociālie priekšstati par mākslu terapiju. [Doctors and teachers social representations about art therapy]. Maǵgistra darbs. RSU. 